\title{
Make Fossil Fuels Great Again? The Paris Agreement, Trump, and the US Fossil Fuel Industry
}

\author{
Lukas Hermwille and Lisa Sanderink*
}

\begin{abstract}
Theoretical advances suggest that international governance in general and the Paris Agreement in particular provide a strong signal guiding sociotechnical systems toward decarbonization. We assess this signal and its effects empirically, by examining the struggle of competing narratives as present in the communications of leading US fossil fuel industry associations and companies. The results are then discussed in the context of the national and international climate and energy policy debates in a study period from late 2014 until the announcement of withdrawal from the Paris Agreement in June 2017. We find that the Paris Agreement has institutionalized a narrative paradigm that is surprisingly resilient. While the election of Donald Trump and his climate and energy policy led to a narrative shift in the coal industry, the oil and gas industry remained conspicuously silent in its immediate response and maintained its narrative strategies despite its alignment with the Paris Agreement.
\end{abstract}

Climate change will transform our global economies and societies, either through catastrophic impacts of unabated climate change or through a fundamental transformation of sociotechnical systems that support our modern societies. At the core of this latter transformation must be a complete turnaround in how we produce and consume energy (see Kuramochi et al. 2018).

It has been argued in the literature that international institutions provide guidance and signals derived from the principles and objectives on which they are based (Hermwille et al. 2017; Oberthür et al. 2017; Young 2017). The Paris Agreement, with its long-term objectives, has sent a strong signal for the required transformation (Bernstein and Hoffmann 2018; Hermwille 2016a; Kinley 2017; Morseletto et al. 2016). However, empirical analyses of the effect of this guidance and signal function remains wanting.

This article traces the signal provided by the Paris Agreement to the people with whom it ultimately needs to resonate: decision makers in the very industries

* The authors thank Philipp Pattberg, Jennifer Hadden, and three anonymous reviewers for valuable feedback on earlier drafts of this article. 
that require transformation toward sustainability. Our case is the US fossil fuel industry. We chose this case because of Donald Trump's attempts to "make fossil fuels great again" by reversing Obama-era climate and energy policy, including by announcing the US withdrawal from the Paris Agreement. This stark policy reversal allows us to assess the Paris signal's resilience against domestic (climate) policy change.

Recent scholarship in global environmental politics has paid increasing attention to the role of nonstate actors-civil society and businesses-in the evolving climate change governance complex (see, e.g., Betsill et al. 2015; Green 2013; Hale 2016; Skjærseth et al. 2013; van der Ven et al. 2017). Not only have private actors become more active in shaping international governance; they are also responding to it, particularly through its authority and clout as provided in the Paris Agreement (Dorsch and Flachsland 2017; Hickmann 2016). This article adds another facet to the discussion by focusing on the discursive effects of the agreement, thereby linking to another stream of literature that is interested in the power of frames, discourses, and narratives in the context of the fossil fuel industry (Downie 2017; Goldthau and Sovacool 2016).

In our case, two competing narratives are at play. While the Paris Agreement was greeted as a beacon of hope to curb anthropogenic climate change for the fossil fuel industry, it implies a story of decline. The victim of this first story is climate and those impacted by climate change. Fossil fuels and, above all, coal are the villains of the story, with respective industries as vicarious agents. As Brian Rickets, secretary-general of the European Association for Coal and Lignite, put it just days after the adoption of the Paris Agreement, "[the coal industry] will be hated and vilified, in the same way that slave traders were once hated and vilified" (quoted in Euractiv 2015). Low-carbon innovation and in particular renewable energies are the heroes of the story.

That narrative is at odds with the historic narrative of the coal, oil, and gas industry, a narrative that Donald Trump has prominently relied on during his presidential campaign and his first year in office. Perhaps the most iconic image was created when Trump held up a "Trump digs coal" sign, put on a miner's hat, and started to mime a historic miner shoveling coal (Marra 2016). In doing so, he associated himself with the miners as heroes of his version of the coal narrative. These brave men risk their lives in the mines and at the wells fighting against nature to produce the coal, oil, and gas that fuel the American Dream.

This narrative struggle is at the heart of our article. We study whether and how the competing narratives are reflected in the official communications of the US fossil fuel industry and how the use of narrative elements has evolved over the study period from late 2014 to President Trump's announcement in June 2017 to withdraw the United States from the Paris Agreement. We will do so by reviewing and analyzing the official communication of three trade associations-the American Coal Council (ACC), the American Coalition for Clean Coal Electricity (ACCCE), and the American Petroleum Institute (API) - as well as the two largest fossil fuel-producing companies: ExxonMobil (oil and gas) and Peabody 
Energy (coal). For the analysis, we apply a narrative policy analysis framework (Jones et al. 2014).

Our research design is inspired by two largely unrelated yet complementary streams of literature: transition research (Geels 2014; Geels and Schot 2010; Hermwille 2016b; Leipprand et al. 2017) and constructivist international relations approaches (Arts 2000; Hermwille et al. 2017; Miskimmon et al. 2013; Wendt 1987). In line with Hermwille (2019), we assume that the Paris Agreement functions as a boundary object (cf. Star and Griesemer 1989) that translates the geophysical implications of global climate change so they become salient in day-to-day decision-making within related sociotechnical systems, in our case, the US fossil fuel industry (also see Rogge and Dütschke 2018). The Paris Agreement can be considered a change in the sociopolitical environment of the fossil fuel industry, thus contributing to a destabilization of the sociotechnical regime (Turnheim and Geels 2013, 20). Narratives and other discursive means have been frequently used to study changes and corresponding adjustments in sociotechnical systems (Bosman et al. 2014; Franceschini and Pansera 2015; Hermwille 2016b; Leipprand et al. 2017; Roberts 2017).

Building on these foundations, we explore two important questions: whether the guidance and signal of the Paris Agreement have an effect on an industry at the core of the climate change problem, and whether we can observe a shift in the use of narratives corresponding to a shift in underlying norms (Bernstein and Hoffmann 2018; Upham et al. 2014). It also allows us to assess how resilient or "entrenched" (Bernstein and Hoffmann 2018) this effect is in relation to counteracting factors, namely, a sea change in domestic policy.

\section{Material and Method}

In this article we delve into the use of narratives and narrative elements in the official communications of the US fossil fuel industry. For this purpose, we applied a narrative policy analysis framework (Jones et al. 2014) because it enables a straightforward and highly transparent analysis of the role of narratives in the policy process. Also, it aligns well with the ontological and epistemological assumptions of the theoretical foundations of our study cited above: (1) it assumes social construction of reality (i.e., meanings are variable), (2) it assumes bounded rationality (i.e., social construction is constrained by belief systems, ideologies, and norms), and (3) it applies a homo narrans model of the individual (postulating that narratives play a key role in how individuals process information and construct reality; cf. Jones et al. 2014, 9-10).

The subject of our research is the official communications of US fossil fuel trade associations and major companies. We studied three trade associations: the ACC, which represents 140 member organizations, including coal suppliers and consumers, coal traders, transportation companies, and service firms; the ACCCE, which comprises thirty-one organizations in the field of coal-based electricity generation, including generators, coal producers, railroads, barge 
operators, and equipment manufacturers; and the API, "the only national trade association representing all facets of the oil and natural gas industry." The API represents more than 625 members, including large integrated companies; exploration and production, refining, marketing, pipeline, and marine businesses; and service and supply firms (American Petroleum Institute 2018). Choosing these trade associations, we achieved near universal representation of the fossil fuel industry.

In terms of major companies, ExxonMobil and Peabody Energy lead their respective industries in terms of the amount of carbon stored in reported reserves (Fossil Free Indexes 2017). ExxonMobil is the largest publicly traded international oil and gas company. In total, it employs more than 71,000 people (ExxonMobil 2018). Peabody Energy is one of the largest private-sector coal companies. It employs 7,200 people and has reported revenues of US\$ 191.5 million in 2017. The company serves costumers of power and steel not only in its home market, the United States, but in twenty-five countries across the globe (Peabody 2018). Beyond these two companies, the selection of organizations was limited for practical reasons. No other major fossil fuel companies (respectively within the top ten of the largest oil and gas and coal companies per amount carbon stored in their reserves) published pertinent data in the study period. Either they did not publish political communication in relation to climate policy or precise publication dates were unavailable.

The time frame of our research begins with the first United States-China Joint Announcement on Climate Change in November 2014 (White House 2014) and ends with the announcement by President Trump in June 2017 that the United States would withdraw from the Paris Agreement (The White House 2017).

We collected data from the websites of the trade associations and selected companies. The study corpus comprises press statements, blog posts, and official reports within the specified time frame. From this large corpus, we studied those statements, posts, and reports that contained a reference to the climate change debate or to the Obama or Trump administration. For this we conducted a simple search for relevant terms on the associations' and companies' websites, such as "climate change," "global warming," "Paris Agreement," "emission reductions," and "Trump." Eventually, this resulted in a data set of 150 relevant press statements, blog posts, and official reports. A list of the considered documents is included in the online appendix (https://www.mitpressjournals.org/ doi/suppl/10.1162/glep_a_00526).

We first analyzed the data using qualitative data analysis software (Atlas.ti 8). ${ }^{1}$ The tools within the software were helpful for managing the large data set, the diverse range of codes, and the illustrative quotations and, more importantly, proved useful for automatic as well as manual coding. For instance, we applied automatic coding to quickly identify particularly relevant passages of the text

1. For more information, see www.atlasti.com, last accessed September 6, 2019. 
containing a reference to national and international climate policy, the climate change issue in general, or political personalities.

Then we analyzed the data manually by building on the categorization of elements according to the narrative policy analysis framework, including settings, characters, and plots, which in combination form a policy narrative that addresses a specific policy problem (Jones et al. 2014).

The setting describes the policy problem and situates it in a specific context. For our study, the setting was mostly predetermined by our research question. Some statements-mostly from API and ExxonMobil-did not speak to climate change and climate policy in general but to more specific policies, such as the political battles on the Keystone XL and Dakota Access pipelines or the moratorium on new offshore oil and gas leases. Much more relevant for our study are

Table 1

Overview of Plot Types Considered

\begin{tabular}{ll}
\hline Plot & Stylized Description \\
\hline Story of decline & $\begin{array}{l}\text { At the beginning things were good, } \\
\text { but now they are worse. This exemplifies } \\
\text { a crisis situation (disaster will follow if } \\
\text { nothing is done). }\end{array}$ \\
Things were terrible, but now everything \\
is getting better. \\
Story of rising and progress & $\begin{array}{l}\text { Things are not getting better because } \\
\text { something/someone is holding us/them back. }\end{array}$ \\
Story of stymied progress & $\begin{array}{l}\text { Things seem to be getting better. But this is just } \\
\text { a superficial impression; things are not actually } \\
\text { improving or are even getting worse. }\end{array}$ \\
Story of illusory progress & $\begin{array}{l}\text { Things were terrible, but then something happened, } \\
\text { and now everything is (quickly) getting better. }\end{array}$ \\
Story of liberation & Life conditions cannot be controlled. We are \\
stooges of our destinies. & The problem is under control; everything will \\
be good. & Control is in the hands of a few, who use it for \\
their own benefit. Harm is deliberately or \\
knowingly caused. \\
Those who suffer from the problem are actually in \\
Conspiracy story
\end{tabular}

Modified from Stone (2012). 
the various characters who can solve the problem (hero), caused the problem (villain), and are harmed by the problem (victim).

Of particular interest was the use of different plots. A plot connects the characters and the policy problem in myriad ways. For this we built on the story types described by Stone $(2012,159-168)$. Table 1 summarizes the various plot types considered in the coding process. For each textual document of the three trade associations and two companies, we coded sentences and parts of texts that contained any of the above mentioned narrative elements. Note that not all narrative elements needed to be present to critically assess the narrative content.

After coding, we looked for common themes, frequently used plots, and characters, to identify common patterns of narrative use. These patterns were then further refined and substantiated by systematically comparing and reflecting the entire data set. Furthermore, we systematically cross-checked each other's analysis to ensure the accuracy and plausibility of the assessment.

We also considered other variables that may influence the use of narratives beyond international and domestic governance. For example, one may expect that trade associations are subject to different incentives than firms and, being more explicitly political organizations, may take on more vociferous narratives. Moreover, the two industries are facing differing degrees of ecological and economic exposure. Economically, the coal industry has been in a steady decline, whereas the oil and gas sector has flourished in recent years. Environmentally, gas features significantly lower carbon emissions per energy unit than coal (also see Downie 2017). The implications of these factors are taken into account in the discussion section.

\section{Results}

\section{Coal Resurrected}

The coal industry associations, the ACC and the ACCCE, use narrative elements frequently in their communications. Over the study period, we observed distinct changes over time with respect to narrative content, particularly the use of plots. The election of Donald Trump as the forty-fifth president of the United States marked a point of inflection. Before the election of President Trump, the communications of the coal industry associations frequently involved a story of decline [e.g., documents $1,5,7,11]^{2}$ or of stymied progress $[2,4,5,6,10,80]$. In one instance, we even observed elements of a conspiracy story [8].

The use of plots in the communications of Peabody Energy is less consistent. For instance, Peabody used a story of decline, which concerns energy poverty being "the most serious crisis that our world faces" [136]. The documents also included two instances of a story of stymied progress [134, 139] inter alia in

2. Hereinafter, document numbers are given in square brackets. 
relation to the "ludicrous" Clean Power Plan of the Environmental Protection Agency (EPA), which is raising electricity prices and putting pressure on American families [134]. Finally, there was one press release with a more positive connotation and a story of liberation applauding the United States-China agreement that supports clean coal technology and recognizes the central role of coal [143].

The trade associations and Peabody Energy also differed slightly in the roles applied in their respective communication. Early in the study period, the trade associations consistently portrayed the coal industry as the victim. On many occasions, we observed an expansion of the victim role to include a larger group, though not consistently across the statements. It sometimes included "all Americans" [8, 15, 16], American families [4, 82], businesses/the economy [4, $16,86]$, taxpayers [10], rate payers [85], or the poorest of the world [6].

Somewhat peculiar, on the other hand, is the fact that Peabody did not victimize itself in its communication, not even in the face of its acute bankruptcy $^{3}$ in April 2016 and thereafter. Rather, it considered itself and its chairman and chief executive officer Greg Boyce to be the heroes of the story, highlighting their "leadership" and "excellence" in advancing low-carbon technologies and energy access and their ability to solve the US electricity crisis [132, 134, 136, 139, 146, 149].

Peabody and the coal industry associations, however, coincided in their choice of villains, using the Obama administration $[8,10,11,82,84,134]$ : either President Obama $[4,80]$ in person, the EPA $[7,9,85,139]$ as his vicarious agent, or the personified Clean Power Plan $[5,80]$. On a few occasions, the villain was a more abstract "Washington bureaucracy" [12] or "job killing regulations" [15]. While the trade associations used strong and vivid language to describe villains, Peabody used more toned-down language. Perhaps the most illustrative example for the vivid formulations of the trade associations was put forward by the ACC in response to President Obama's decision to issue a moratorium on new coal leases, describing it as "one more slice in the administration's 'death by a thousand cuts' policies enacted against coal" [8]. Here and consistently across the communication, the causal relationship implied is intentional, implying or stating that the Obama administration was actively trying to harm the US coal industry by waging a "war against coal" [84].

In the communication of the trade associations, an active hero was mostly absent. On some occasions, though, the coal industry portrayed itself as a hero, albeit as a hero in chains. This was especially pertinent whenever an international/ global setting was used $[3,4,6]$. A peculiar finding is that the coal industry even portrayed itself as a hero to combat climate change. In the ACC's own words, "There will be no low carbon world without low carbon coal" [6]. The industry frequently highlighted its past achievements of reducing emissions $[3,6,16]$ and the importance of "high efficiency, low emissions (HELE) technologies" as a climate change

3. The US business of Peabody Energy filed for Chapter 11 bankruptcy on April 13, 2013, citing an "unprecedented industry downturn" (Mooney and Mufson 2016). Peabody recovered economically and left behind bankruptcy protection only one year later (Reuters 2017). 
solution $[6,7,132,133,144,145,146,149]$. In this context, Peabody sang its own praise as a leader of "sustainable mining, energy access and clean coal solutionswhat Peabody calls 'Coal Done Right'" [149, also see 132, 145, 149].

With the election of Donald Trump, we observed a significant narrative shift. This shift was characterized by a new dominant plot that was applied widely across the communications of US coal trade associations: a story of liberation $[15,16,82,85]$. Donald Trump and his ally EPA director Scott Pruitt were portrayed as the saviors of the coal industry [14, 15, 16, 80, 84, 85]. The heroic appraisal of Scott Pruitt is particularly striking. In the trade associations' view, Pruitt would tame the rogue EPA [e.g., 14].

While Peabody also welcomed the election of Trump and his subsequent reversal of US climate and energy policy $[133,144,145]$, it did so in a much more toned-down way. Peabody did not embrace the same story of liberation, nor did it glorify President Trump and/or Scott Pruitt as a hero. Instead, it promoted a story of control. While most press releases did not explicitly claim to have the problem fully under control, they argued that if coal were "done right," according to their recommendations, the problem would be "under control" [132, 133, 144, 145, 146, 149].

The narrative shift came with another feature: the absence of victims. After the election of President Trump, the statements of the trade associations and Peabody no longer featured any acute victims. If at all, the victim role was only assigned in retrospect in reference to the pre-Trump period. According to the coal industry, everybody wins with the rollback of the Clean Power Plan and the withdrawal of the Paris Agreement, even the environment. In responding to President Trump's announcement of the US's plan to withdraw from the Paris Agreement, the ACC highlighted that "America is an environmental leader and the administration's decision does not diminish that. ... Emissions reductions globally will be furthered by the continued development and deployment of these clean energy technologies" [16].

So how is the coal industry portrayed in the communications of the three organizations investigated? Especially in the earlier phase, the trade associations portrayed the coal industry as a variety of antihero. On one hand, the coal industry was the victim of government overreach. The "illegal Clean Power Plan" had "hamstrung the industry for the last eight years" [80]. At the same time, the industry was portrayed as a frustrated hero that needed to be unleashed to rebuild the American economy and, ultimately, save the world. The policy change of the Trump administration would now enable the coal industry to assume its designated role as a genuine and positive hero.

Peabody, on the other hand, did not buy in to this narrative. It did not portray itself as the victim of climate and energy policy. This is a peculiar finding, given that Peabody, when filing for bankruptcy, was a victim in objective terms. We can only speculate, but the dire economic situation of the company may also be one explanation for this narrative strategy. Portraying oneself as a victim suggests that one's own agency is limited and that one cannot take fate 
into one's own hands. Promoting a narrative in which Peabody is portrayed as a victim could help to explain the economic turmoil, but it could also undermine creditors' and investors' confidence in Peabody and its ability to recover.

\section{Oil and Gas Industry: Everything Under Control}

The communications from the oil and gas industry represented by the API and ExxonMobil evidently embraced narrative elements. The use of plots was relatively consistent over time. The central argument was that natural gas production is key to tackling the global climate change challenge.

We detected a range of different plots in the communication of both the API and ExxonMobil, including stories of decline [55, 56, 57, 58, 67, 77], illusory progress $[51,52,70]$, stories of rising and progress [50,70], stories of control [e.g., 54, 59, 60, 63, 76, 88, 89, 92, 96, 98, 100, 101, 115-119, 124-127, $131]$, and even conspiracy stories [68, 97, 99-103, 105-107, 111, 120, 121, 129]. Upon closer inspection, though, we discovered a still more consistent pattern. The API utilized more negative plots-stories of decline or illusory progresswhenever it referred to specific policy actions or regulations, such as the matter of approval/rejection of the Keystone XL pipeline [e.g., 52, 68], the freezing of new leases for oil and gas production in the Arctic [46, 61, 67], or the EPA's Renewable Fuel Standard (RFS) [58, 77]. Also, the one instance of a conspiracy story in API's communication was related to a concrete policy action-President Obama's rejection of the Keystone XL pipeline-referring to it as "a clear example of politics coming before the interests of US workers and consumers," as "politics at its worst," and as "an assault against American workers" [68].

Meanwhile, whenever API referred more generally to climate change or provided a general outlook, it applied more positive plots, particularly stories of progress [50, 70] and stories of control [e.g., 54, 59, 60, 63, 76]. Exxon was even more consistent in its choice of narrative and almost exclusively applied a story of control $[88,89,92,96,98,100,101,115-119,124-127,131]$.

There are also several instances in which ExxonMobil applied a conspiracy story narrative $[97,99-103,105-107,111,120,121,129]$. However, all of these instances relate to the so-called \#ExxonKnew campaign, in which a group of environmental activists and journalists accused ExxonMobil of having disregarded its own climate research and instead of having engaged in political lobbyism to counter effective climate policies, because they would negatively affect its business. In this narrative, ExxonMobil clearly portrayed itself as a victim of conspiracy.

The use of characters was largely consistent among API and Exxon. In contrast to the coal industry, the oil and gas industry was not portrayed as a victim (with the exception of the \#ExxonKnew campaign); rather, the American people were. More specifically, "consumers" and "motorists" [58, 63, 77] and "American workers" $[56,63,68]$ were the affected ones. In a few instances, the victimcharacter was more abstract, for example, "American competitiveness" [55, 56] 
or "US energy security" [68]. A feature of the story of control plot is that it generally gives little prominence to victims. That is why both victims are mostly absent in ExxonMobil's communication. Occasionally, the role of victim is filled by people in developing countries who lack access to modern energy and who need to be lifted out of (energy) poverty [89, 98, 121].

The use of character differed among API and Exxon in that the API designated the Obama administration, its regulations, and the EPA as villains, or rather, as culprits. Aside from the document involving a conspiracy plot, we did not detect signs of malicious intentionality; rather, the regulations and decisions of Obama's administration and the EPA were perceived as well intended yet executed in a negligent and/or misinformed manner [50, 51, 55, 56, 63]. This included Obama's offshore oil and natural gas leasing program [e.g., 56, $61,67]$, the EPA's RFS [58, 77], and Obama's rejection of the Keystone XL pipeline [e.g., 68]. In Exxon's communication, again as a corollary to the dominant story of control narrative, a villain was largely absent.

A recurring argument is that despite the administration's and EPA's mismatched regulations and decisions, America still managed to realize an "energy renaissance" $[50,52,62,65,69,93,94,98,117,118,125]$ and to evolve into a "global energy super power" [29, 50, 52, 76]. While not always explicit, Exxon and the oil and gas industry are the heroes that enabled this transformation [e.g., 51, 52, 65, 78, 100, 115].

In this regard, the industry's characterization of the climate change problem is notable. The API hardly ever mentioned "climate change" explicitly. Instead, most communication referred to "emission reductions" [e.g., 21, 23, 38, $40,65]$ or to "the environment" and "environmental progress" [e.g., 18, 35, 23]. Exxon, in turn, employed a strategy of issue expansion and uniformly referred to the "dual challenge of minimizing greenhouse gas emissions while ensuring the world has adequate access to affordable and reliable supplies of energy" [128; see also 88, 91, 92, 96, 97, 11, 114, 115, 123-127, 130]. ExxonMobil portrayed the latter part of that dual challenge almost as an inescapable fate of humanity. Still, thanks to "abundant low-carbon resources such as natural gas" [131], ExxonMobil and the natural gas industry, as the heroes of the story, have everything under control. ExxonMobil portrayed itself as an organization driven by a "scientific and engineering mindset" [100] that is at the forefront of providing "solutions to environmental and climate-related challenges" [115].

The adoption of the Paris Agreement in November 2015 reinforced the narrative strategy of the oil and gas industry. The plot choice of story of control became even more dominant. The industry highlighted that the United States was leading the world's emission reductions and was well on its way to achieving the Paris Agreement emission reduction targets [29, 70, 71, 73, 75].

The election of Donald Trump changed little with respect to the use of narrative elements. Exxon did not at all comment on the election of Donald Trump and his climate and energy policy stance, not even as Rex Tillerson, Exxon's longtime chairman and chief executive officer, was nominated to be 
the administration's first secretary of state. API was more appreciative of the election of Trump and EPA chief administrator Scott Pruitt [17, 18, 19, 41, $42,48]$, who were portrayed as heroes even though the industry had already had "everything" under control for a long time. Yet, there is not nearly the same level of glorification of the administration compared to the communications of the coal trade associations.

Perhaps the most peculiar finding of our analysis is the oil and gas industry's reaction to President Trump's announcement to withdraw the United States from the Paris Agreement: there was no reaction! In March 2017, Exxon had still urged the Trump administration to continue to support the Paris Agreement in a letter sent to the White House [131]. But after the announcement, in the Rose Garden of the White House, both Exxon and the API remained conspicuously silent. $^{4}$

To summarize, according to the API and Exxon, the oil and gas industry has played a central role in the energy renaissance, transforming the United States into a global energy superpower. More specifically, market-driven solutions provided by the natural gas industry were portrayed as essential to ensuring economic growth, job creation, and affordable and reliable energy supply, while at the same time reducing greenhouse gas emissions. The message is clear: the oil and gas industry has everything under control.

\section{Discussion}

We discuss our results in relation to three distinct dimensions of analysis. First, we discuss commonalities and differences among the two industries in the light of the ongoing political discussions on the national and international levels. Second, we discuss the influence that the Paris Agreement and President Trump's announcement to withdraw the United States from it have had on the two industries and to what extent that has led to a shift in the use of narrative strategies. Finally, we discuss what we can generalize from our chosen case with respect to the effectiveness of the guidance and signal provided by the Paris Agreement and its resilience toward domestic policy reversal.

One could suspect that the narratives of the coal industry, on one hand, and of the oil and gas industry, on the other, may be similar. Our analysis, however, reveals more differences than commonalities (also see Downie 2017). One key difference regards the character of the villain. The coal trade associations clearly portray the Obama administration and the EPA as malicious villains that intentionally stifled the coal industry. Meanwhile, the oil and gas industry acknowledges the Obama administration's general intention to address climate

4. Just one day before President Trump's announcement, 62 percent of ExxonMobil's shareholders, including the company's largest investors, voted to request the company to report regularly on the impacts of climate change policies on their business, against the recommendation of the Exxon management. The company did not issue a public statement in response to this vote. 
change. In the API's communication, the Obama administration and the EPA are portrayed in a much less hostile way. The EPA is not a villain but rather a culprit. The "crime" is not an attack against the industry but negligence and/or flawed execution. As expected, the analyzed companies, both Exxon and Peabody, do not use the same explicit political language as their respective trade associations, which are, of course, much more evidently political organizations. Consequently, Exxon's and Peabody's characterizations of villains are more subtle.

A second key difference is the shift in the use of narrative elements by the coal industry. The election of Donald Trump makes for a convenient plot twist that almost naturally fits into the existing storyline of the coal industry (also see Downie 2017). Effectively, Trump and Pruitt are portrayed as the saviors of coal industry and yield the promise of resolution of the story and a happy end for the coal industry. Yet, although the election of Donald Trump may have resolved the struggle of the coal industry in narrative terms, there is little that points to its resurrection in reality. At best, Trump provided very short-lived relief for the industry. Today, the industry is continuing to decline, and at a similar pace as before (Eckhouse and Loh 2017).

Meanwhile, the oil and gas industry is fairly consistent in its use of narrative elements. The industry portrays itself as a key solution to the climate problem. And in fact, at least in the short term, the industry has contributed significantly to the drop in US $\mathrm{CO}_{2}$ emissions in recent years, although the contribution may be smaller than what the US gas industry may want to take credit for (Mohlin et al. 2018). Correspondingly, as the industry's exposure to immediate policy risks is comparatively lower, it was perhaps easier for the oil and gas industry to choose more constructive narratives. What is more, Bach $(2019,88)$ attests that some oil and gas companies have begun "to consider the very real possibility that oil and gas will no longer play a central role in our energy systems and ... they could become locked out of a low-carbon future." To avoid this, they are actively seeking opportunities in new business models, development of new technologies, and optimization of processes (Bach 2019).

Consequently, the adoption of the Paris Agreement only seems to have reinforced the dominant story of control plot. Surprisingly, not even the election of Donald Trump and his announcement to withdraw from the Paris Agreement have had a fundamental impact on the industry's narrative strategy. Trump's policy reversal challenges the narrative of the oil and gas industry: it is incompatible with the industry's own storyline. After the Paris Agreement, the oil and gas industry missed no occasion to assert that with their help the climate change problem is or will be under control. Trump's policy reversal undermines this narrative. It suggests that there is nothing to be controlled, and consequently no role for the industry in doing the controlling. This interpretation is supported by the fact that neither the API nor Exxon applauded or in any way commented on Trump's announcement of US withdrawal from the Paris Agreement. 
This brings us to the second question: what is the influence of the Paris Agreement on the two industries, and to what extent did its adoption influence their communication? The adoption of the Paris Agreement did not have a major influence on the coal industry's narrative strategy. This is not surprising, as the agreement's implicit narrative is fundamentally at odds with the coal industry's narratives. Finding a convincing and constructive role for the coal industry within the new paradigm seems to be a lost cause. The oil and gas industry, in turn, had already embraced a narrative strategy ${ }^{5}$ that was aligned, or at least not completely irreconcilable, with the Paris Agreement and its narrative paradigm. The Paris Agreement seems to have reinforced the industry's narrative strategy even further. The "conspicuous silence" of the industry after President Trump's announcement is perhaps the most peculiar finding of our analysis. This (non) reaction, as well as the continued use of a story of control plot, serves as evidence for a surprisingly high degree of resilience in terms of narrative strategy.

Finally, what can we generalize from the analyzed case? While generalizations building on individual cases are always difficult, there are some exceptions to that rule (Flyvbjerg 2006). One such exception is whenever the selected case is "critical" in the sense that it "permits logical deductions of the type, "if this is (not) valid for this case, then it applies to all (no) cases'" (Flyvbjerg 2006).

The case of the US fossil fuel industry is in several ways such a critical case. First is that practices of the fossil fuel industry and particularly the coal industry are called into question by the Paris Agreement like no other sector. Given this extreme exposure, it is fair to say that what we observe in the fossil fuel sector is very likely also to hold for less exposed sectors. To illustrate, if President Trump's policy reversal does not affect the oil and gas industry and its future expectations as expressed in its public communications, it is likely that the same effect will apply to less exposed sectors.

Second, the US case is critical in the sense that the Paris Agreement was to a great extent designed to accommodate the special circumstances of the US political system (Obergassel et al. 2015, 2016). Yet the Unites States is the only country that so publicly and completely reversed its climate policy after the Paris Agreement has entered into force. So if we observe that the oil and gas industry's communicative alignment with the paradigm institutionalized by the Paris Agreement is resilient to President Trump's announcement to withdraw from the Paris Agreement, it is very likely that the Paris paradigm is also robust against lesser political variations.

Our methodology focuses on the (strategic) use of communication. This focus does, of course, not allow us to make any inferences as to the meaning of changes in the use of narratives for day-to-day decision-making in the industries and whether that affects investment practices, which will ultimately decide

5. As of 2009, ExxonMobil has publicly acknowledged the existence of anthropogenic climate change and advocated for a revenue-neutral carbon tax. At the same time, however, Exxon has publicly opposed any practical attempts to introduce specific climate change legislation in the United States (Schwartz 2017). 
whether we can meet well below the 2 degree Celsius objective of the Paris Agreement. However, as Göpel (2016) argues a "mindshift" is an essential prerequisite for a fundamental transformation of actual practices. In that sense, our research suggests that indeed, international governance supports such a mindshift.

\section{Conclusions}

In the past few years, a narrative struggle evolved with regard to the US fossil fuel industry, with two major political events underlying it: the adoption of the Paris Agreement and the election of Donald Trump as the forty-fifth president of the United States. When comparing the strategic uses of narrative of the coal industry and the oil and gas industry, the results show that there are significant differences between them. However, for the coal industry, Obama's administration is a clear villain intentionally stifling the industry, the oil and gas industry acknowledges the general intentions of the Obama administration, though it finds the execution to be negligent or flawed.

We conclude that the dramatic policy reversal epitomized by President Trump's announcement to withdraw the United States from the Paris Agreement has resonated differently and did not (fully) undermine the paradigm institutionalized by the Paris Agreement. While Trump's election and his climate and energy policy led to a major narrative shift in the coal industry, the oil and gas industry has not reacted in the same way. The Paris Agreement has reinforced the industry's narrative strategy and the way in which it has portrayed itself as part of the solution to control the climate issue. The industry's "conspicuous silence" after Trump's policy reversal-the withdrawal-suggests that the Paris paradigm is surprisingly resilient.

Our analysis supports the hypothesis that international governance provides guidance and signal that resonate with decision makers in the private sector. In metaphorical terms, the Paris Agreement has turned the rudder. However, a ship does not turn in an instant. Before the tacking maneuver is complete, the ship will face head winds and enter into a phase of uncertainty, with the sails luffing and no propulsion. Our analysis shows that President Trump's announcement to withdraw the United States from the Paris Agreement did not reverse the maneuver. It rather represents some of the headwinds, admittedly a strong gust, that are to be expected. It remains to be seen whether there is enough momentum to complete the shift and gather way in a new direction.

Lukas Hermwille is a project coordinator at the Wuppertal Institute for Climate, Environment, and Energy. His work focuses on market-based mitigation instruments as well as questions of the overall governance architecture of the climate regime. He leads the Wuppertal Institute's contribution to the EU-funded COP21:RIPPLES (www.cop21ripples.eu) project on the adequacy of the Paris Agreement, and he has worked on the transformation of energy sectors from 
a global perspective. He is a $\mathrm{PhD}$ candidate at IVM Institute for Environmental Studies at Vrije Universiteit Amsterdam, the Netherlands.

Lisa Sanderink is a researcher and PhD candidate in the Department of Environmental Policy Analysis at the Institute for Environmental Studies (IVM), Vrije Universiteit Amsterdam, the Netherlands. Her research focuses on understanding institutional complexity of global climate and energy governance and examines coherence and effectiveness across renewable energy institutions, particularly multistakeholder partnerships. She is a member of the CLIMENGO project (www.climengo.eu) and a research fellow with the Earth System Governance network.

\section{References}

American Petroleum Institute. 2018. About API. Available online at: www.api.org/about, last accessed September 6, 2019.

Arts, Bas. 2000. Regimes, Non-state Actors and the State System: A "Structurational" Regime Model. European Journal of International Relations 6 (4): 513-542.

Bach, Matthew. 2019. The Oil and Gas Sector: From Climate Laggard to Climate Leader? Environmental Politics 28 (1): 87-103.

Bernstein, Steven, and Matthew Hoffmann. 2018. The Politics of Decarbonization and the Catalytic Impact of Subnational Climate Experiments. Policy Sciences 51 (2): 189-211.

Betsill, Michele M., Navroz K. Dubash, Matthew Paterson, Harro van Asselt, Antto Vihma, and Harald Winkler. 2015. Building Productive Links Between the UNFCCC and the Broader Global Climate Governance Landscape. Global Environmental Politics 15 (2): $1-10$.

Bosman, Rick, Derk Albert Loorbach, Niki Frantzeskaki, and Till Pistorius. 2014. Discursive Regime Dynamics in the Dutch Energy Transition. Environmental Innovation and Societal Transitions 13: 45-59.

Dorsch, Marcel J., and Christian Flachsland. 2017. A Polycentric Approach to Global Climate Governance. Global Environmental Politics 17 (2): 45-64.

Downie, Christian. 2017. Fighting for King Coal's Crown: Business Actors in the US Coal and Utility Industries. Global Environmental Politics 17 (1): 21-39.

Eckhouse, Brian, and Tim Loh. 2017. Coal's Trump Bump Is Over. Available online at: www.bloomberg.com/news/articles/2017-11-08/a-year-after-trump-s-electioncoal-s-still-losing-to-renewable, last accessed September 6, 2019.

Euractiv. 2015. Coal Lobby Chief: COP21 Means "We Will Be Hated Like Slave Traders." Available online at: www.euractiv.com/section/energy/news/coal-lobby-chiefcop21-means-we-will-be-hated-like-slave-traders/, last accessed September 6, 2019.

ExxonMobil. 2018. Learn About the History of ExxonMobil. Available online at: https:// corporate.exxonmobil.com/en/company/about-us/history/overview, last accessed September 6, 2019.

Flyvbjerg, Bent. 2006. Five Misunderstandings About Case-Study Research. Qualitative Inquiry 12 (2): 219-245. 
Fossil Free Indexes. 2017. The Carbon Underground 2017: Managing Energy Transition Risk in Investment Portfolios. Available online at: http://fossilfreeindexes.com/ research/the-carbon-underground/, last accessed September 6, 2019.

Franceschini, Simone, and Mario Pansera. 2015. Beyond Unsustainable Eco-innovation: The Role of Narratives in the Evolution of the Lighting Sector. Technological Forecasting and Social Change 92: 69-83.

Geels, Frank W. 2014. Regime Resistance Against Low-Carbon Transitions: Introducing Politics and Power into the Multi-level Perspective. Theory, Culture, and Society 31 (5): 21-40.

Geels, Frank W., and Johan Schot. 2010. The Dynamics of Transitions: A Socio-technical Perspective. In Transitions to Sustainable Development: New Directions in the Study of Long Term Transformative Change, edited by John Grin, Jan Rotmans, and Johan Schot, 11-104. New York: Routledge.

Goldthau, Andreas, and Benjamin K. Sovacool. 2016. Energy Technology, Politics, and Interpretative Frames: Shale Gas Fracking in Eastern Europe. Global Environmental Politics 16 (4): 50-69.

Göpel, Maja. 2016. The Great Mindshift. Cham, Switzerland: Springer International.

Green, Jessica F. 2013. Rethinking Private Authority: Agents and Entrepreneurs in Global Environmental Governance. Princeton, NJ: Princeton University Press.

Hale, Thomas. 2016. "All Hands on Deck": The Paris Agreement and Nonstate Climate Action. Global Environmental Politics 16 (3): 12-22.

Hermwille, Lukas. 2016a. Climate Change as a Transformation Challenge: A New Climate Policy Paradigm? GAIA: Ecological Perspectives for Science and Society 25 (1): 19-22.

Hermwille, Lukas. 2016b. The Role of Narratives in Socio-technical Transitions: Fukushima and the Energy Regimes of Japan, Germany, and the United Kingdom. Energy Research and Social Science 11: 237-246.

Hermwille, Lukas. 2019. Global Climate Governance as Boundary Object: Making the Meaning of the Anthropocene. In The Anthropocene Debate and Political Science, edited by Thomas Hickmann, Lena Partzsch, Philipp Pattberg, and Sabine Weiland, 103-123. Oxon, UK: Routledge.

Hermwille, Lukas, Wolfgang Obergassel, Hermann E. Ott, and Christiane Beuermann. 2017. UNFCCC Before and After Paris: What's Necessary for an Effective Climate Regime? Climate Policy 17 (2): 150-170.

Hickmann, Thomas. 2016. Rethinking Authority in Global Climate Governance: How Transnational Climate Initiatives Relate to the International Climate Regime. Oxon, UK: Routledge.

Jones, Michael D., Elizabeth A. Shanahan, and Mark K. McBeth, eds. 2014. The Science of Stories: Applications of the Narrative Policy Framework in Public Policy Analysis. New York: Palgrave Macmillan.

Kinley, Richard. 2017. Climate Change After Paris: From Turning Point to Transformation. Climate Policy 17 (1): 9-15.

Kuramochi, Takeshi, Niklas Höhne, Michiel Schaeffer, Jasmin Cantzler, Bill Hare, Yvonne Deng, Sebastian Sterl, Markus Hagemann, Marcia Rocha, Paola Andrea YanguasParra et al. 2018. Ten Key Short-Term Sectoral Benchmarks to Limit Warming to $1.5^{\circ}$ C. Climate Policy 18 (3): 287-305.

Leipprand, Anna, Christian Flachsland, and Michael Pahle. 2017. Advocates or Cartographers? Scientific Advisors and the Narratives of German Energy Transition. Energy Policy 102: 222-236. 
Marra, Ashton. 2016. "Trump Digs Coal" at Charleston Rally. West Virginia Public Broadcasting. Available online at: www.wvpublic.org/post/trump-digs-coal-charleston-rally, last accessed September 6, 2019.

Miskimmon, Alister, Ben O'Loughlin, and Laura Roselle. 2013. Strategic Narratives: Communication Power and the New World Order. New York: Routledge/Taylor and Francis.

Mohlin, Kristina, Jonathan R. Camuzeaux, Adrian Muller, Marius Schneider, and Gernot Wagner. 2018. Factoring in the Forgotten Role of Renewables in $\mathrm{CO}_{2}$ Emission Trends Using Decomposition Analysis. Energy Policy 116: 290-296.

Mooney, Chris, and Steven Mufson. 2016. How Coal Titan Peabody, the World's Largest, Fell into Bankruptcy. Washington Post. Available online at: www.washingtonpost. com/news/energy-environment/wp/2016/04/13/coal-titan-peabody-energy-filesfor-bankruptcy/, last accessed September 6, 2019.

Morseletto, Piero, Frank Biermann, and Philipp Pattberg. 2016. Governing by Targets: Reductio Ad Unum and Evolution of the Two-Degree Climate Target. International Environmental Agreements: Politics, Law and Economics 17: 655-676.

Obergassel, Wolfgang, Christof Arens, Lukas Hermwille, Nicolas Kreibich, Florian Mersmann, Hermann E. Ott, and Hanna Wang-Helmreich. 2015. Phoenix from the Ashes: An Analysis of the Paris Agreement to the United Nations Framework Convention on Climate Change-Part I. Environmental Law and Management 27: 243-262.

Obergassel, Wolfgang, Christof Arens, Lukas Hermwille, Nicolas Kreibich, Florian Mersmann, Hermann E. Ott, and Hanna Wang-Helmreich. 2016. Phoenix from the Ashes: An Analysis of the Paris Agreement to the United Nations Framework Convention on Climate Change-Part II. Environmental Law and Management 28: 3-12.

Oberthür, Sebastian, Lukas Hermwille, Gauri Khandekar, Wolfgang Obergassel, Tim Rayner, Tomas Wyns, Florian Mersmann, Damon Jones, Bianca Kretschmer, and Mahlet Melkie. 2017. Key Concepts, Core Challenges and Governance Functions of International Climate Governance. Paris: COP21 RIPPLES Project (Horizon2020). Available online at: www.cop21ripples.eu/wp-content/uploads/2017/02/Deliverable-4.1-RipplesFinal2.pdf, last accessed September 6, 2019.

Peabody. 2018. Peabody-All About Peabody. Available online at: www.peabodyenergy. com/Who-We-Are/All-About-Peabody, last accessed September 6, 2019.

Reuters. 2017. Peabody Energy Emerges from Bankruptcy Protection. April 3.

Roberts, Cameron. 2017. Discursive Destabilisation of Socio-technical Regimes: Negative Storylines and the Discursive Vulnerability of Historical American Railroads. Energy Research and Social Science 31: 86-99.

Rogge, Karoline S., and Elisabeth Dütschke. 2018. What Makes Them Believe in the LowCarbon Energy Transition? Exploring Corporate Perceptions of the Credibility of Climate Policy Mixes. Environmental Science and Policy 87: 74-84.

Schwartz, John. 2017. Tillerson Led Exxon's Shift on Climate Change; Some Say "It Was All P.R." New York Times, December 22.

Skjærseth, Jon Birger, Guri Bang, and Miranda A. Schreurs. 2013. Explaining Growing Climate Policy Differences Between the European Union and the United States. Global Environmental Politics 13 (4): 61-80.

Star, Susan Leigh, and James R. Griesemer. 1989. Institutional Ecology, "Translations" and Boundary Objects: Amateurs and Professionals in Berkeley's Museum of Vertebrate Zoology, 1907-39. Social Studies of Science 19 (3): 387-420. 
Stone, Deborah. 2012. Policy Paradox: The Art of Political Decision Making. 3rd ed. New York: W. W. Norton.

Turnheim, Bruno, and Frank W. Geels. 2013. The Destabilisation of Existing Regimes: Confronting a Multi-dimensional Framework with a Case Study of the British Coal Industry (1913-1967). Research Policy 42 (10): 1749-1767.

Upham, Paul, Paula Kivimaa, Per Mickwitz, and Kerstin Åstrand. 2014. Climate Policy Innovation: A Sociotechnical Transitions Perspective. Environmental Politics 23 (5): 774-794.

van der Ven, Hamish, Steven Bernstein, and Matthew Hoffmann. 2017. Valuing the Contributions of Nonstate and Subnational Actors to Climate Governance. Global Environmental Politics 17 (1): 1-20.

Wendt, Alexander. 1987. The Agent-Structure Problem in International Relations Theory. International Organization 41 (3): 335-370.

White House. 2014. US-China Joint Announcement on Climate Change. Available online at: https://obamawhitehouse.archives.gov/the-press-office/2014/11/11/us-chinajoint-announcement-climate-change, last accessed September 6, 2019.

White House. 2017. Statement by President Trump on the Paris Climate Accord. Available online at: https://www.whitehouse.gov/briefings-statements/statementpresident-trump-paris-climate-accord/, last accessed September 10, 2019.

Young, Oran R. 2017. Governing Complex Systems: Social Capital for the Anthropocene. Cambridge, MA: MIT Press. 